\title{
Seksualitas dalam Alquran, Hadis dan Fikih: Mengimbangi Wacana Patriarki
}

\author{
Neng Hannah \\ Fakultas Ushuluddin UIN Sunan Gunung Djati Bandung \\ Jl. AH. Nasution No. 105 Cibiru, Bandung, Jawa Barat, Indonesia \\ E-mail: nenghannah79@gmail.com
}

\begin{abstract}
Discussing sexuality is often misunderstood only to be associated with sexual relations. In fact, sexuality is associated not only with biological aspect but also with experiences and expressions of the human being as a sexual agent. It is related to one's thought, feeling, and expression related to being sexual. Sexuality is a social construction that related to norms, values, and behaviors in different context. In Muslim society, sexuality has dual meanings: Sometimes discussing sexuality is appreciated but at the same time is prevented. This article explains sexuality from Islamic perspectives derived from Quran, Hadith, and Jurisprudence (Fiqh). This article shows that sexuality in Muslim society is influenced by cultural norms and religious doctrines. Doctrines derived from Quran, Hadith and Fiqh give significant influence on how people think and act concerning what is permitted and forbidden, appropriate and inappropriate related to being male and female. The explanations on sexuality in the Quran, Hadith, and Fiqh, in fact, appreciate human being as natural sexual being and fulfilling for both sexes. However, in reality, the dominant understandings of those sources are heavily influenced by patriarchal bias.
\end{abstract}

Keywords:

Fiqh, Hadith; Quran;sex; sexuality.

\begin{abstract}
Abstrak
Ketika kita membincang tentang seksualitas, sering disalahfahami sebagai bahasan yang hanya berbicara tentang seks. Padahal cakupan bahasan seksualitas lebih luas daripada sekedar soal seks yang lebih mengacu pada aspek biologis. Seksualitas ialah bagaimana seseorang mengalami, menghayati dan mengekspresikan diri sebagai makhluk seksual. Dengan kata lain tentang bagaimana seseorang menggunakan pikiran, menggunakan perasaan dan bertingkahlaku berdasarkan posisinya sebagai makhluk seksual. Konsep seksualitas akan berbeda sesuai tempat dan waktu, karena merupakan konsep dan kontruksi sosial terhadap nilai dan perilaku yang berkaitan dengan seks. Isu seksualitas diperbincangkan secara ambigu di dunia Muslim. Ia sering dibicarakan dengan penuh apresisasi, tetapi dalam waktu yang sama juga sangat tertutup dan konservatif. Tulisan ini bermaksud untuk memaparkan tentang seksualitas dalam perspektif Islam dengan landasan sumber dari Alquran, Hadis dan Fikih. Tulisan ini menunjukkan bahwa seksualitas dalam Islam dibentuk oleh nilai budaya dan agama. Nilai-nilai agama dalam Alquran, Hadis dan Fikih mewarnai pembentukan pandangan tentang apa yang boleh dilakukan atau tidak, berbagai keharusan, dan sikap yang dikembangkan sehubungan dengan peran jenis kelamin. Pandangan tentang seksualitas dalam Islam yang dijelaskan dalam ayat Alquran, Hadis dan Fikih sebenarnya begitu humanis dan sangat sejuk karena penuh empati kemanusiaan. Namun hal tersebut tidak banyak disosialisasikan di kalangan masyarakat Islam. Sebaliknya, pandangan yang banyak dijumpai atau pandangan dominan sangat bias nilai-nilai patriarki.
\end{abstract}

\section{Kata Kunci:}

Alquran; fikih; hadis; seks; seksualitas.

DOI: $10.15575 / \mathrm{jw} . \mathrm{v} 2 \mathrm{i} 1.795$

Received: June 2016; Accepted: January 2017; Published: June 2017

\section{A. PENDAHULUAN}

Seksualitas adalah sebuah kata menarik yang sering diperbincangkan secara tertutup maupun terbuka. Dari kalangan rakyat biasa sampai politisi negara. Seksualitas sering diidentikan dengan seks. Hal ini tidaklah keliru. Namun seksualitas bukan hanya tentang seks. Seks dan seksualitas merupakan dua hal yang berbeda. Seks berhubungan dengan masalah biologis pada perempuan dan lelaki, sementara seksualitas sangat luas cakupannya tidak hanya pada aspek biologis 
semata. Sebelum kita membicarakan lebih lanjut tentang seksualitas ada baiknya kita memahami kata kunci mengenai masalah seksualitas, yaitu istilah seks, seksual dan seksualitas.

Kata "seks" dapat berarti perbedaan karakter jenis kelamin (jenis kelamin biologis) dan bisa juga mengenai segala hal yang berkenaan dengan organ-organ kemaluan serta terkait dengan percumbuan serta hubungan badan (coitus). Kata seksual adalah berkenaan dengan tingkah laku, persamaan atau emosi yang digabungkan dengan rangsangan organorgan kemaluan daerah erogenous, atau disebut proeses reproduksi. Sedangkan "seksualitas" adalah kapasitas untuk memiliki atau untuk mengusahakan hubungan persetubuhan, bisa juga dimaksudkan karakter yang sedang tertarik pada sudut pandang seksual. Seksualitas adalah tentang bagaimana seseorang mengalami, menghayati dan mengekspresikan diri sebagai makhluk seksual, dengan kata lain tentang bagaimana seseorang berpikir, merasa dan bertindak berdasarkan posisinya sebagai makhluk seksual. Segala sesuatu yang ada kaitannya dengan seks (ada kaitan dengan kelamin) tercakup di dalamnya. Hubungan seks hanyalah salah satu aspek, namun secara umun seksualitas memang selalu dihubungkan dengan hubungan seks (persetubuhan). ${ }^{1}$

Konsep seksualitas akan berbeda sesuai tempat dan waktu, karena merupakan konsep dan kontruksi sosial terhadap nilai dan perilaku yang berkaitan dengan seks. ${ }^{2}$ Perbedaan ini bukan hanya dalam makna seksualitas antar kebudayaan, tetapi juga dalam pemaknaan yang ada dalam budaya itu sendiri. Hal ini menurut Saptari yang dikutip dari Truongh karena diskursus seksualitas mengatur tiga dimensi kehidupan manusia yang meliputi: pertama, dimensi biologis yaitu yang menyangkut kegiatan seks sebagai

\footnotetext{
${ }^{1}$ Stevi Jackson dan Sue Scott, Feminism And Sexuality: A Reader (New York: Colombia University Press, 1993), 62.

2 Agus Dwiyanto dan Muhadjir, eds., Seksualitas, Kesehatan Reproduksi dan Ketimpangan Jender (Jakarta: Pustaka Sinar Harapan, 1996), 260.
}

kenikmatan biologis atau untuk mendapatkan keturunan. Kedua, dimensi sosial yang meliputi hubungan-hubungan antara individu yang melakukan hubungan seks secara sah atau tidak sah (menurut ukuran masyarkat yang bersangkutan). Ketiga, dimensi subjektif yang berhubungan dengan kesadaran individu terhadap seksual diri sendiri atau kelompok ${ }^{3}$. Dengan batasan yang begitu luas, seksualitas menjadi sebuah diskursus yang menyangkut perilaku jenis kelamin sekaligus sebagai seperangkat gagasan yang membentuk norma. Keduanya saling berhubungan satu sama lain.

Isu seksualitas dibicarakan secara ambigu di dunia Muslim. Ia sering dibincangkan dengan penuh apresisasi, tetapi dalam waktu yang sama juga sangat tertutup dan konservatif. Keadaan ini muncul sebagai konsekuensi dari dua pola keberagamaan Islam, yakni pola keberagamaan Islam-ideal dan Islam-sejarah. Pola Islam ideal mengapresiasi seksualitas sebaga fitrah manusia. Seks adalah anugerah Tuhan. Hasrat seksual harus dipenuhi sepanjang manusia membutuhkannya dan ini hanya ada dalam pernikahan. Islam ideal menghendaki relasi kesetaraan, keadilan dan kemaslahatan. Sedangkan Islam-sejarah sering dipengaruhi oleh ideologi-ideologi yang bias gender. Sehingga seks dipandang sebagai sesuatu yang buruk bahkan lawan dari spiritualitas.

Pembahasan dalam tulisan ini menggunakan teknik studi pustaka yang menelaah berbagai buku, literatur serta catatan yang berkaitan dengan seksualitas yang terdapat di dalam Alquran, hadis dan fikih. Diharapkan pembahasan tentang seksualitas dalam tulisan ini bisa mengimbangi wacana patriarki yang memandang seksualitas sebagai lawan dari spiritualitas dan dipandang tabu. Selain juga untuk memperlihatkan bahwa dalam Alquran, hadis dan fikih, Islam memandang seksualitas sebagai bagian penting dari relasi manusia yang bersifat humanis dan sejuk serta penuh empati kemanusiaan.

\footnotetext{
${ }^{3}$ Thanh-Dam Truongh, Seks, Uang dan Kekuasaan: Pariwisata dan Pelacuran di Asia Tenggara (Jakarta: LP3ES, 1992), xxiii.
} 


\section{B. HASIL DAN PEMBAHASAN 1. Seksualitas dalam Alquran}

Berbicara seksualitas dalam Alquran harus dilakukan secara hati-hati mengingat masalah ini merupakan masalah yang sangat krusial. Alquran sebetulnya tidak spesifik menjelaskan perihal seksualitas. Tetapi juga tidak menghindar dari pembicaraan ini. Pembicaraan tentang seksualitas dalam Alquran lebih cenderung kepada relasi seksual sebagai suami istri ketimbang seks sebagai hak asasi individu. Maka, pembicaraan nikah sebagai pelembagaan relasi sosial-seksual memperoleh penjelasan yang cukup lengkap dibanding dengan seksual sebagai hak setiap orang.

Persoalan-persoalan seksualitas yang disinggung oleh Alquran antara lain meliputi hal-hal seperti, perkawinan, perceraian, perlakuan suami istri di dalam kehidupan rumah tangga (muasyarah bil ma'ruf), iddah dan persoalan yang berkaitan dengan penyimpangan seksual seperti kisah kaum Luth yang mempraktikkan homoseksualitas. Hal ini menunjukan bahwa sebagai kitab suci, Alquran merupakan kitab yang merespon persoalanpersoalan kemanusiaan.

Pada dasarnya ada dua misi kenapa Alquran berbicara tentang seksualitas. Pertama, pembicaraan ini dimaksudkan untuk melakukan counter terhadap sejarah seksualitas masa lalu. Masa lalu yang dimaksud adalah masa-masa sebelum kedatangan Islam atau yang sering kita sebut masa jahiliah. Terhadap masa-masa pra-Islam ini nampaknya Alquran mempunyai pandangan yang peyoratif (memberikan makna menghina). Menurut Islam, seksualitas pra Islam adalah model seksualitas yang tidak teratur dan tidak beradab. Seksualitas praIslam identik dengan pergaulan bebas longgar dan tidak terkendali. Selain itu, seksualitas pada masa itu juga mencerminkan relasi lakilaki dan perempua yang tidak seimbang. ${ }^{4}$

Jauh sebelum kehadiran Islam, masyarakat jahiliah melakukan praktik pernikahan dengan memiliki ratusan bahkan ribuan istri, harem, selir dan pergundikan banyak terjadi. Terdapat beragam jenis perkawinan yang merupakan

\footnotetext{
${ }^{4}$ Syafiq Hasyim, Bebas dari Patriarkhisme Islam (Jakarta: Kata Kita, 2010), 224-225.
}

praktik perilaku seksual pada masa jahiliah ini sehingga kemudian dilarang. Bentuk-bentuk pernikahan yang dilarang tersebut adalah: 1) Nikah al-Maqt yaitu menikahi bekas istri ayah yang sudah meninggal, 2) Nikah al-Syighar yaitu pertukaran anak perempuan tanpa mahar, 3) Nikah al-Istibdha' yaitu pernikahan dengan menempatkan perempuan sebagai bida'ah atau barang dagangan, 4) Nikah al-Rahth yaitu pernikahan untuk kepuasan seksual tanpa batasan jumlah istri, 5) Nikah al-Badal atau praktik tukar-menukar istri, dan 6) nikah alBaghaaya atau hidup bersama tanpa nikah (kumpul kebo). ${ }^{5}$

Kedua, pembicaraan ini juga dimaksudkan untuk membuat aturan-aturan dari pola seksualitas yang tidak beragama (tidak berdasarkan syari'ah) menuju pola seksualitas yang beragama (berdasarkan syariah). Semua tindakan yang mengatasnamakan seks dalam Islam tidak bisa berlangsung tanpa mendapatkan legitimasi. Di sini mulai muncul batasanbatasan dan aturan-aturan yang harus dipatuhi oleh seseorang yang ingin melakukan seks. Misalnya dalam kasus poligami, yang tadinya seorang laki-laki bisa mengawini sebanyak mungkin perempuan, dengan munculnya Islam, seorang laki-laki diberi batas maksimal empat istri. $^{6}$

Alquran lebih banyak berbicara tentang karakteristik dan perilaku seksual manusia daripada tentang seksualitas manusia (identitas seksual yang merupakan kontruksi sosial). Inti pandangan Alquran tentang kedua pandangan tersebut adalah bahwa laki-laki dan perempuan memiliki karakteristik seksual yang sama (gagasan tentang kesamaan seksual). Karena itu Alquran mendukung pandangan yang tidak membedakan seksualitas karena tidak melekatkan tipe identitas, dorongan, atau kecenderungan terhadap perilaku seksual tertentu kepada salah satu jenis kelamin. Misalnya Alquran tidak mendukung gagasan tentang kebobrokan dan kepasifan seksual perempuan

\footnotetext{
${ }^{5}$ Halim Barkat, Dunia Arab, trans. Irfan M Zakki (Bandung: Nusa Media, 2012).140.

${ }^{6}$ Barkat, Dunia Arab, 141.
} 
maupun seksualitas laki-laki yang serba jahat dan menyimpang. ${ }^{7}$

Hal mendasar dalam konsep Alquran tentang seks/seksualitas ialah Alquran tidak membuat klaim yang merendahkan perempuan dan seks, bahkan menentang tradisi misoginis. ${ }^{8}$ Hal ini terlihat dalam Alquran yaitu:

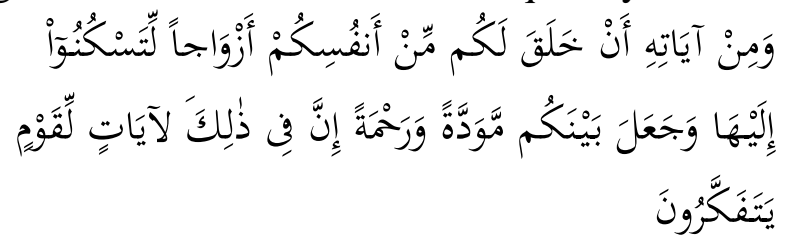

Artinya: Di antara tanda tanda kekuasaan Tuhan adalah bahwa Dia menciptakan pasangan untukmu dari jenismu sendiri, supaya kamu cenderung dan merasa tentram kepadanya (Sukun), dan dijadikanNya di antara kamu kasih sayang. Sesungguhnya pada yang demikian itu benar-benar terdapat tanda-tanda bagi kaum yang berfikir (QS 30: 21).

Ayat ini sering dikemukakan untuk menjawab bagaimana Islam memberikan apresiasinya terhadap seksualitas. Ada sejumlah tujuan yang hendak dicapai dari pernikahan ini. Pertama, sebagai cara manusia menyalurkan hasrat libidonya untuk memperoleh kenikmatan/kepuasan seksual. Kedua, merupakan ikhtiar manusia untuk melestarikan kehidupan manusia di bumi. Pernikahan dalam arti ini mengandung fungsi prokreasi sekaligus reproduksi. Ketiga, menjadi wahana manusia menemukan tempat ketenangan dan keindahannya. Melalui perkawinan, kegelisahan dan kesusahan hati manusia mendapatkan salurannya. ${ }^{9}$

Barlas menjelaskan Alquran surat 30 ayat 21 ini sebagai berikut: Sukun yang sering diterjemahkan dengan cinta, mengandung arti keintiman mendalam yang disebabkan oleh pemenuhan seksual dan kedamaian mental. Penggunaannya dalam Alquran dinilai penting karena dua alasan: pertama, ia menunjukan

\footnotetext{
${ }^{7}$ Asma Barlas, Cara Qur'an Membebaskan Perempuan (Jakarta: Serambi, 2003), 267.

${ }^{8}$ Barlas, Cara Qur'an Membebaskan Perempuan,

${ }^{9}$ Husein Muhammad, "Íslam, Seksualitas dan Budaya," Swara Rahima 20, no. XII (2012), 23-24.
} 267. bahwa Islam menuntut agar hubungan seksual/perkawinan didasarkan pada rasa saling cinta, keharmonisan dan kepuasan, sebuah pandangan yang bila ditinjau dari masa pewahyuan Alquran merupakan sesuatu yang sangat revolusioner. Dengan menekankan sikap saling memberi dan menerima kepuasan seksual Alquran menegaskan bahwa laki-laki dan perempuan keduanya memiliki dorongan dan kebutuhan seksual serta hak untuk memenuhinya. Kedua dengan mendefinisikan seks dalam pengertian yang menyiratkan kesenangan dan kepuasan seksual, Alquran juga menegaskan bahwa seks bukan saja bertujuan untuk memperbanyak keturunan, seks juga merupakan aktivitas yang menyenangkan dan bertujuan menciptakan sukun. ${ }^{10}$

Ayat ini menjadi penting karena dua alasan lain. Pertama ia menunjukan bahwa berbeda dengan tradisi dualistik, Alquran tidak memosisikan seksualitas sebagai lawan dari spiritualitas. Ia justru memandang seksualitas sebagai "tanda" kemurahan dan karunia Tuhan kepada manusia. Alquran juga tidak mengaitkan seks/seksualitas dengan perilaku hewani atau tindakan jasmani semata. Jadi Alquran tidak menyatakan-seperti yang dilakukan oleh kebanyakan muslim - bahwa "naluri seksual" kelemahan terbesar umat manusia. ${ }^{11}$ Sebaliknya Alquran memandang seks "sebagai sarana Tuhan untuk menciptakan hubungan antara laki-laki dan perempuan yang dicirikan oleh kebersamaan, kedamaian, cinta dan kasih sayang. ${ }^{12}$

Kedua, ayat ini seperti banyak ayat lainnya, menegaskan bahwa laki-laki dan perempuan memiliki karakteristik yang sama/serupa, termasuk karakteristik seksual. Keduanya merupakan bagian integral dari keseluruhan karakteristik alami manusia (fitrah). Bahkan, kesamaan/keserupaan karakteristik (seksual)

\footnotetext{
${ }^{10}$ Muhammad, "Íslam, Seksualitas dan Budaya", 269.

${ }^{11}$ Ini pendapat Maududi yang dikutip oleh Riffat Hassan, "An Islamic Perspective", dalam Karena Lebacqz, Sexuality: A Reader, ed. Karena Lebacqz (Claveland, Ohio: The Pilgrim Press, 1999), 351.

${ }^{12}$ Lebacqz, Sexuality: A Reader, 351.
} 
manusia itulah yang membuat sukun yang timbal balik itu menjadi bermakna dan mungkin.

Tidak adanya pembedaan Alquran antara karakteristik seksual laki-laki dan perempuan juga terbukti dari konsepnya tentang keberpasangan laki-laki dan perempuan dalam berbagai persoalan yang memperlihatkan kesepadanan/keserupaan keduanya. Misalnya Alquran menyatakan:

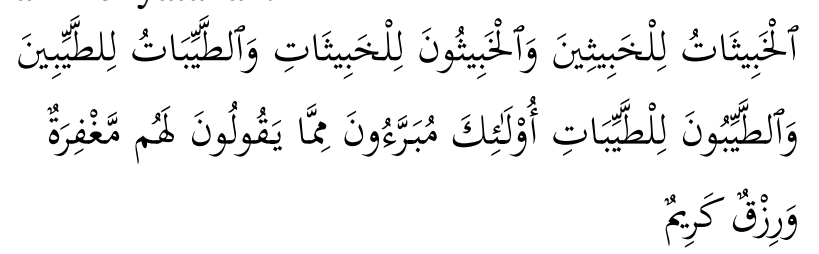

Artinya: Perempuan-perempuan yang keji adalah untuk lelaki lelaki yang keji dan lelaki lelaki yang keji adalah untuk perempuan perempuan yang keji dan perempuan perempuan yang baik adalah untuk lelaki lelaki yang baik, dan lelaki-lelaki baik adalah untuk perempuan-perempuan yang baik (QS 24:26).

Dengan menegaskan bahwa laki-laki dan perempuan secara seksual bisa menjadi suci atau ternoda, dan bahwa perempuan beriman seperti halnya laki-laki beriman, memiliki hak untuk menikahi pasangan yang masih suci. Ayat ini menggugat pandangan muslim tentang perempuan sebagai sosok yang bobrok secara seksual di satu sisi dan pengaitan kesucian (yang biasanya didefinisikan sebagai keperawanan) hanya kepada perempuan di sisi lainnya. Bagaimanapun, Alquran tidak hanya menekankan kesucian perempuan semata, seperti yang telah dipaparkan di atas. Lebih jauh, menurut al-Qur'an, kesucian dan kehormatan didasarkan pada perilaku, bukan pada identitas atau jenis kelamin, dan itulah sebabnya mengapa Alquran menerapkan konsep kesucian setara terhadap laki-laki dan perempuan. Hal ini dinyatakan dalam ayat lain:

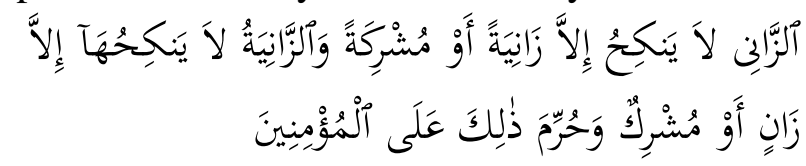

Artinya: "Laki-laki yang berzina tidak mengawini melainkan perempuan yang berzina, atau perempuan musyrik dan perempuan berzina tidak dikawini melainkan oleh laki-laki yang berzina atau orang laki-laki musyrik dan yang demikian itu diharamkan atas orang-orang mukmin (QS 24: 3).

Moralitas seksual atau kesucian seseorang terkait dari perilaku bukan dari karakteristik atau jenis kelaminnya. Lebih jauh, kesucian bukan berarti tidak melakukan aktivitas seksual, melainkan tidak melakukan jenis perilaku seksual tertentu (perzinahan dan pelacuran), menjaga kehormatan, menghindari hal-hal yang mendorong perzinahan dan sebagainya. Bahkan dalam Alquran, persyaratan untuk menahan diri dari pernikahan, kebolehan untuk menikah, dan kehidupan dalam pernikahan, semuanya dimaksudkan untuk menjaga kehormatan dan menghindari perilaku seksual yang nista, tak terkontrol atau tidak bertanggung jawab, baik oleh laki-laki maupun perempuan. Menurut Alquran, kesucian merupakan buah dari perilaku dan karena buah dari, pilihan moral dan seksual yang dibuat seseorang bukan buah dari karakteristik, identitas, agama ataupun kelas sosialnya. ${ }^{13}$

Selajutnya salah satu ayat Alquran yang popular dijadikan rujukan tentang hubungan seksual diantara suami istri adalah surat alBaqarah ayat 223, adapun bunyinya:

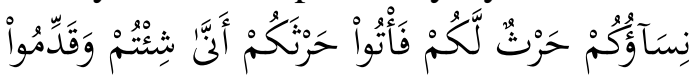

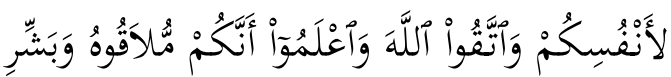

$$
\begin{aligned}
& \text { ألْمَْْْمِنينَ }
\end{aligned}
$$

Artinya: Istri-istrimu adalah (seperti) tanah tempat kamu bercocok-tanam, maka datangilah tanah tempat bercocok-tanammu itu bagaimana saja kamu kehendaki. Dan kerjakanlah (amal yang baik) untuk dirimu, dan bertakwalah kepada Allah dan ketahuilah bahwa kamu kelak akan menemui-Nya. Dan berilah kabar gembira orang-orang yang beriman.

Ayat di atas menggambarkan relasi seksual suami dan istri. Bila memahaminya sekilas, tergambar bahwa seksualitas perempuan adalah pasif dan sebaliknya seksualitas lelaki

\footnotetext{
${ }^{13}$ Barlas, Cara Qur'an Membebaskan Perempuan, 272.
} 
harus aktif, terutama ketika berhubungan seks. Ladang menjadi metafor perempuan sedangkan laki-laki si penanam bibit. Sehingga sebagai ladang, istri/perempuan bisa kapan saja dan ditanami apa saja sesuai dengan keinginan suami/laki-laki.Dengan kata lain, perempuan adalah objek kemauan laki-laki khususnya dalam soal seks.

Penafsiran seperti ini diantaranya terdapat dalam Tafsir al-Azhar Hamka. Hamka menafsirkan ayat ini terutama tentang maksud "istri sebagai sawah ladang" bahwa istri ibarat sawah ladang tempat suami menanam benih untuk menyambung keturunan, dan suami sebagai pemilik sawah ladang boleh masuk ladang kapanpun dia suka dan mau, namun dalam menanam benih juga harus memperhatikan pada saat yang tepat agar tidak siasia. $^{14}$

Penafsiran dan pemahaman demikianlah yang umum berkembang di tengah-tengah masyarakat. Pemahaman ini membentang lebar dari zaman unta hingga zaman nuklir, dari Barat hingga Timur. Bisa jadi segala bentuk diskriminasi, subordinasi, dan 'fitnah' atas seksualitas perempuan yang selama ini beroperasi melalui ajaran keagamaan, seperti ajaran khitan-perempuan dan pengharusan istri untuk memenuhi hasrat seksualitas suami, bersumber dari pemahaman dan penafsiran terhadap ayat ini. Padahal pemahaman dan penafsiran ini tidak memiliki dasar penafsiran yang sahih kecuali sebagai bias dari kukuhnya budaya dan alam pikir patriarki yang menyelimuti para mufassir dan khalayak dari masa ke masa. ${ }^{15}$

Ayat di atas kalau dilihat dari sebab turunnya (sabab al-nuzul) tidak memojokkan perempuan bahkan menempatkan perempuan pada posisi yang terhormat. Menurut Madsar F Masudi, ayat ini turun pada dasarnya berkaitan dengan kegemaran sebagian laki-laki yang suka menggauli istrinya lewat dubur. Islam melarang praktik tersebut dengan mengingatkan bahwa istri dengan rahimnya

\footnotetext{
${ }^{14}$ Hamka, Tafsir al-Azhar, II (Jakarta: Pustaka Panjimas, 1983), 214-215.

${ }^{15}$ Marzuki Wahid, "Mendaulatkan Seksualitas Perempuan," Swara Rahima 5, no. II (2009), 38.
}

(ladang) bagi laki-laki untuk menanam benih keturunannya. Maka janganlah kalian tanam benih tadi tidak pada tempatnya (dubur). Selain merupakan sesuatu yang tidak pada tempatnya, perbuatan tersebut dari sisi kesehatan juga kurang aman. Jadi jelas, pesan ayat itu bukan untuk memperlakukan perempuan semaunya, seolah ayat ini menjelaskan teknik bermain seks belaka. Rasanya terlalu sepele hal tersebut diangkat oleh Alquran. ${ }^{16}$

Lebih dari itu, penggambaran perempuan sebagai ladang dalam konteks masyarakat madinah saat itu sebenarnya mengisyaratkan tingginya nilai perempuan. ${ }^{17}$ Ladang merupakan sesuatu yang terbatas dan jarang di Madinah. Tidak jarang beberapa kabilah berperang untuk mendapatkan tempat yang subur untuk menjadi ladang. Karena nilainya begitu tinggi maka nyawa pun bisa dikorbankan untuk mendapatkannya. Berbeda hal dengan konteks Indonesia, dimana ladang adalah sesuatu yang biasa saja nilainya. Sehingga metafor perempuan sebagai ladang merupakan penggambaran betapa tingginya nilai seorang perempuan yang harus dijaga, dirawat dan dihormati karena perjuangan mendapatkannya tidak mudah.

Selanjutnya Ayat di atas juga memberi pengertian bahwa istri "laksana sawah ladang" yang siap digarap kapan saja ketika suami menghendaki. Dalam ayat ini terkandung pengertian suatu bentuk kehati-hatian sekaligus menjaga betul perihal kualitas benih dan metode penanamannya, sehingga tidak terkesan dipaksakan. Jadi harus ada interaksi antara keduanya yang diharapkan dapat membuat lahan itu subur dan produktif. Dengan demikian seorang suami memiliki tanggung jawab terhadap "ladang" yang diamanati Allah. Ladang tersebut perlu dirawat dengan baik dengan dicangkul, disiram, diberi pupuk dan disayang agar tetap subur. Hubungan suami istri dalam sebuah perkawinan adalah ibadah, namun bukan berarti hak seksualitas perem-

\footnotetext{
${ }^{16}$ Masdar F Masudi, Islam \& Hak-hak Reproduksi Perempuan (Bandung:Mizan, 2000), 121.

${ }^{17}$ Masdar F. Mas'udi, Islam Dan Hak-Hak Reproduksi Perempuan: Dialog Fiqh Pemberdayaan (Bandung: Mizan, 1997).
} 
puan ditiadakan, justru dimensi ibadah inilah yang membawa substansi pada keikhlasan masing-masing pihak tanpa adanya pemaksaan terhadap pasangan. $^{18}$

Untuk penjelasan tentang relasi struktural seksual suami dan istri mengacu kepada QS al-Baqarah: 187 yang berbunyi:

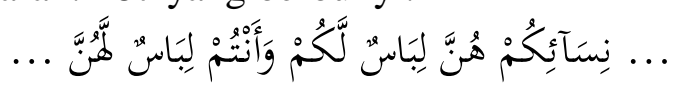

Artinya: Mereka (istri) itu adalah pakaian bagimu dan kamu pun adalah pakaian bagi mereka. (QS. al-Baqarah[2]: 187)

Ibnu Jarir al-Thabari, guru besar para ahli tafsir, mengemukakan dua tafsir atas ayat ini. Pertama, ayat ini adalah metafora untuk arti penyatuan dua tubuh secara interaktif. Kedua, mengutip ahli tafsir Mujahid Qatadah, ayat ini berarti masing masing pasangan saling memberi ketenangan bagi yang lainnya. ${ }^{19}$ Hubungan seksualitas suami dan istri dalam Alquran yang dijelaskan ayat ini merupakan suatu hubungan yang setara, saling melengkapi, dan saling membutuhkan sebagai partner dalam menyalurkan hasrat seksualnya.

Alquran mesti kita posisikan secara proporsional, sebagai aturan (norma dan nilai) yang universal, yang bersendikan keadilan, kemaslahatan, dan mengangkat harkat dan derajat kemanusiaan. Positioning ini perlu dilakukan, terutama, dalam memahami ayatayat yang berhubungan dengan seksualitas dan relasi gender. Ini dilakukan karena Alquran diturunkan pada abad ke-7 M di kawasan Arabia yang, secara sosiologis, masyarakatnya memiliki konstruk dan persepsi kebudayaan yang diskriminatif mengenai perempuan. Tatanan yang berlaku pada masyarakat jazirah Arabia ketika Alquran turun adalah sistem patriarki atau kebapakan, suatu budaya yang dibangun di atas struktur dominasi laki-laki sebagai pusat kuasa. Perempuan, dalam kebudayaan mereka, diposisikan dan diperlakukan sedemikian rendah dan hina. Kebiasaan

\footnotetext{
${ }^{18}$ Andi Dermawan, "Marital Rape Dalam Perspektif Hukum Al-Qur'an," in Tela'ah Ulang Wacana Seksualitas, ed. Mochammad Sodik, I (Yogyakarta: PSW IAIN Sunan Kalijaga, Depag RI dan McGillIISEP-CIDA, 2004). 303.

${ }^{19}$ Abu Ja'far Muhammad bin Jarir Al-Thabari, Jami' Al-Bayan Fi Tafsir Al-Qur'an, III (t.p., n.d.).489.
}

yang bisa dicatat dari budaya mereka terhadap perempuan adalah pembunuhan bayi perempuan, pelecehan seksual terhadap (budak) perempuan, peniadaan hak waris bagi kaum perempuan, dzihar, poligami tanpa batas, menceraikan perempuan sesuka lelaki, dan lain-lain $^{20}$

Oleh karena itu, memahami ayat-ayat Alquran tidak bisa hanya berhenti pada teks semata, melainkan harus menyertakan bacaan konteks sosial-budaya kapan dan di mana teks itu terbentuk. Membaca ayat Alquran tentang seksualitas tanpa membaca konstruk kebudayaan masyarakat Jazirah Arabia saat itu hanya akan menghilangkan misi emansipatoris yang tersirat dalam setiap maknanya.

Posisi perempuan saat ayat-ayat Alquran diturunkan berada dalam anggapan yang buruk, bahkan sampai menjadi keyakinan bahwa perempuan adalah makhluk sumber 'fitnah', lemah, mewarisi kejahatan, tidak mempunyai kemampuan intelektual, dan kosong dari spiritualitas; karena itu, perempuan "tidak setara dengan kaum lelaki". Konsekuensinya, perempuan dianggap tidak mampu dan tidak laik untuk memikul peranperan publik dan segala hal yang memiliki akses ke dalam wilayah publik. Perempuan dicukupkan hanya mengurusi, bukan mengatur, hal-hal yang berada pada wilayah domestik belaka. ${ }^{21}$

Dalam latar sosio-budaya demikianlah, di antaranya, Alquran diturunkan sebagai jawaban, bantahan, dan alternatif nilai untuk membangun kembali tata kebudayaan yang adil. Benar, apa yang dikatakan oleh Fazlur Rahman bahwa Alquran merupakan respon Allah yang disampaikan melalui Rasul-Nya untuk menanggapi situasi sosial-moral pada masa Nabi. Alquran dan asal usul masyarakat Islam muncul dalam sinaran sejarah dan berhadapan dengan latar belakang sosialhistoris. Alquran merupakan respon terhadap situasi tersebut dan sebagian besar kandungannya terdiri dari pernyataan moral, religius, dan

\footnotetext{
${ }^{20}$ Ashgar Ali Engineer, Hak-Hak Perempuan Dalam Islam, terj. Farid Wajidi dan Cici Farkha Assegaf (Yogyakarta: Yayasan Bentang Budaya, 1994), 55.

${ }^{21}$ Engineer, Hak-Hak Perempuan Dalam Islam,55.
} 
sosial, sebagai respon terhadap masalah spesifik yang dihadapkan kepadanya dalam situasi-situasi yang konkret. ${ }^{22}$

Alquran hadir dengan weltanschauung (pandangan hidup) sendiri. Secara tegas, Alquran mengakui adanya perbedaan anatomis dan biologis antara seksualitas perempuan dan seksualitas laki-laki. Alquran juga mengakui bahwa organ seks berfungsi dengan cara yang mencerminkan perbedaan yang dibatasi dengan baik oleh kebudayaan tempat Alquran berada. Alquran tidak berusaha menghapus perbedaan anatomis dan biologis itu, juga tidak menghilangkan signifikansi perbedaan yang kudrati itu. Tetapi juga Alquran tidak pernah membuat aturan yang secara kultural menjadikan perbedaan seks itu dapat diperlakukan secara diskriminatif, subordinatif, dan dominatif atas yang lain. Sebab ketentuanketentuan kultural semacam itu (jika ada) akan bertentangan dengan skala fungsi Alquran sendiri yang bersifat universal, lintas kultural, melampaui batas ruang dan waktu. ${ }^{23}$

\section{Seksualitas dalam Hadis}

Pembicaraan mengenai seksualitas dalam masyarakat muslim tidak bisa lepas dari hadis Nabi. Karena hadis merupakan ucapan, tindakan dan persetujuan Rasul atas suatu peristiwa yang biasanya memiliki kaitan langsung dengan kondisi sosial-budaya masyarakat yang terjadi pada masa itu, maka persoalan seksualitas lebih detail dibicarakan. Namun, berbicara tentang hadis Nabi sesungguhnya adalah berbicara tentang sejarah (sirah) kehidupan Nabi.

Sesungguhnya pengalaman praktis Nabi dengan persoalan seksualitas terjadi ketika beliau melakukan perkawinan dengan Khadijah. Perkawinan Nabi dengan Khadijah ini telah mengajarkan banyak hal kepada kita tentang makna seksualitas dalam kehidupan rumah tangga. Dikatakan bahwa perkawinan Rasulullah dengan Khadijah, meminjam teori

\footnotetext{
${ }^{22}$ Wahid, "Mendaulatkan Seksualitas Perempuan", 39.

${ }^{23}$ Wahid, "Mendaulatkan Seksualitas Perempuan",39
}

Mernissi, ${ }^{24}$ menunjukan sebuah fenomena seksualitas perempuan yang aktif yang selama ini dilihat "rendah" oleh kalangan Islam. Dalam hal ini Khadijahlah yang melamar Rasulullah.

Namun, fenomena yang begitu jelas itu sering tidak dipahami oleh kaum muslim yang menempatkan seksualitas perempuan dalam posisis yang pasif. Hal ini tercermin dalam ulasan-ulasan ulama fiqih tentang tradisi khitbah di mana seorang laki-lakilah yang melakukannya. Khitbah (meminang) dengan cara demikian itu merupakan langkah awal dari upaya penaklukan seksualitas perempuan. Sejarah Islam mencatat bahwa Rasulullah menerima pinangan tidak hanya dari Khadijah, tapi juga dari istri-istri yang lain. Tindakan Rasulullah yang itu mengisyaratkan kepada kita semua bahwa seksualitas aktif perempuan tidak menjadi masalah serius.

Mernissi melihat pembagian masyarakat tersebut sebenarnya tidak tergantung kepada mekanisme internalisasi, tetapi lebih kepada konsep seksualitas perempuan yang berkembang dalam suatu masyarakat. Menurutnya, apabila dalam suatu masyarakat berlaku pengucilan dan pencadaran perempuan, maka konsep seksualitas yang berkembang dalam masyarakat tersebut adalah perempuan aktif dan apabila sebaliknya, maka konsep seksualitasnya pasif.

Namun apabila kita kembalikan kepada apa yang telah dialami Rasulullah dengan istri-istri beliau, maka sesungguhnya aktif atau pasif tidaklah begitu signifikan selama stereotype yang ditempelkan pada laki-laki baik yang pasif atau aktif maupun perempuan baik aktif maupun pasif tidak merugikan keduanya. Hanya selama ini ada kecenderungan bahwa seksualitas aktif kaum perempuan dianggap tabu oleh agama. Pandangan demikian sepintas tidak menjadi masalah dan sering dipahami sebagai perlindungan terhadap martabat kaum perempuan. Namun soal seksualitas sebenarnya tidak hanya terkait dengan perkara yang lahir (sensual), tetapi

\footnotetext{
${ }^{24}$ Fatima Mernissi, Beyond The Veil: Seks dan Kekuasaan Dinamika Pria Wanita dalam Masyarakat Muslim Modern (Surabaya: Al-Fikr, 1997), 109.
} 
juga terkait dengan yang lain. Dari akibat pandangan seksualitas perempuan pasif ini, misalnya perempuan diposisikan sebagai pekerja domestik yang tidak boleh keluar rumah. Tindakan represif yang mengatasnamakan agama ini menjadikan perempuan kehilangan haknya untuk melakukan aktivitas baik dalam bidang sosial maupun keilmuan. ${ }^{25}$

Di antara hadis yang sering jadi rujukan hubungan seksual suami-istri ialah hadis tentang intervensi malaikat dalam hubungan suami-istri. Hadis ini diantaranya:

1. Ahmad bin Hanbal hadis no 9294:

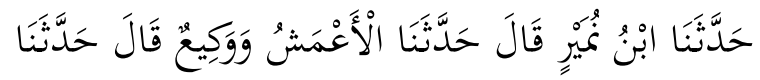

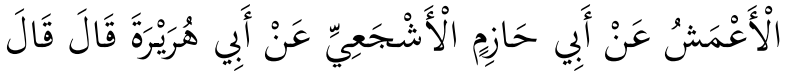

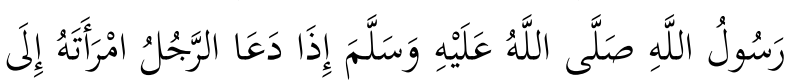

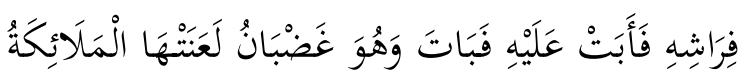

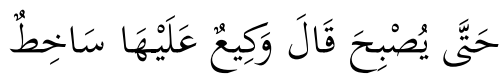

Telah menceritakan kepada kami (Ibnu Numair) telah menceritakan kepada kami (Al A'masy) dan (Waki') berkata; telah menceritakan kepada kami (Al A'masy) dari (Abu Hazim Al Asyja'i) dari (Abu Hurairah) berkata; Rasulullah shallallahu 'alaihi wasallam bersabda: "Jika seorang laki laki memanggil istrinya ke tempat tidur lalu ia enggan memenuhinya sehingga suaminya tidur dalam keadaan marah, maka para malaikat melaknatnya sehingga datang waktu subuh." Waki' menyebutkan, "Ia marah kepada istrinya." (HR. Ahmad ibn Hanbal). ${ }^{26}$

2. Dalam kitab Sahih Muslim kitab nikah, hadis no 2595.

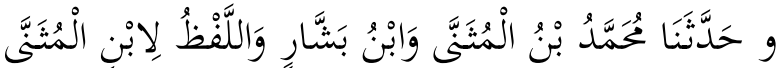

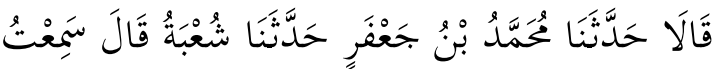

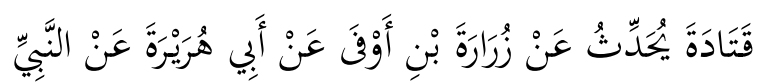

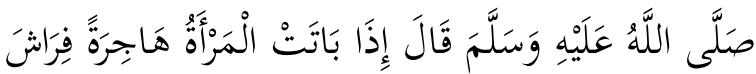

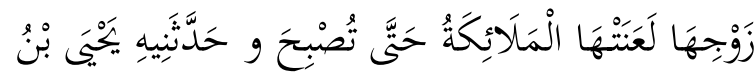

\footnotetext{
${ }^{25}$ Hasyim, Bebas dari Patriarkhisme Islam, 230.

${ }^{26}$ Musnad Ahmad Kitab 6, Bab 30, Hadis 9294.
}

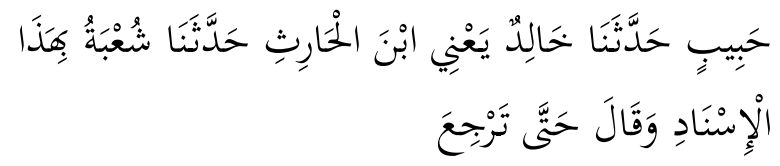

Dan telah menceritakan kepada kami (Muhammad bin Al Mutsanna) dan (Ibnu Basysyar) sedangkan lafazhnya dari $\mathrm{Al}$ Mutsanna keduanya berkata; Telah menceritakan kepada kami (Muhammad bin Ja'far) telah menceritakan kepada kami (Syu'bah) dia berkata; Saya pernah mendengar (Qatadah) telah menceritakan dari (Zurarah bin Aufa) dari (Abu Hurairah) dari Nabi shallallahu 'alaihi wasallam, beliau bersabda: "Apabila seorang istri enggan bermalam dengan memisahkan diri dari tempat tidur suaminya, maka Malaikat akan melaknatnya sampai pagi." Dan telah menceritakan kepadaku (Yahya bin Habib) telah menceritakan kepada kami (Khalid) yaitu Ibnu Al Harits, telah menceritakan kepada kami (Syu'bah) dengan isnad ini, beliau bersabda: "Sampai dia (istri) kembali (kepada suaminya)." (HR. Muslim). ${ }^{27}$

3. Hadis yang diriwayatkan oleh Bukhari kitab nikah hadis no 4794.

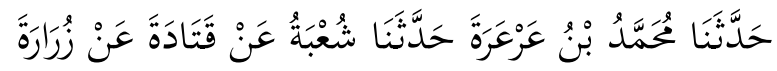

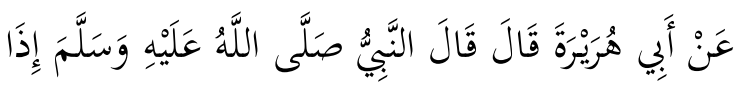

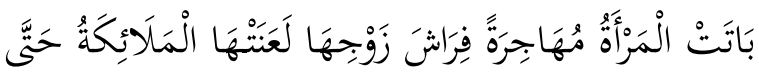

$$
\text { تَرْنجعَ }
$$

Telah menceritakan kepada kami (Muhammad bin 'Ar'arah) Telah menceritakan kepada kami (Syu'bah) dari (Qatadah) dari (Zurarah) dari (Abu Hurairah) ia berkata; Nabi shallallahu 'alaihi wasallam bersabdda: "Apabila seorang wanita bermalam sementara ia tidak memenuhi ajakan suaminya di tempat tidur, maka Malaikat melaknatnya hingga pagi." (HR Bukhari). ${ }^{28}$

\section{Abu Daud hadis no 1829}

\footnotetext{
${ }^{27}$ Shahih Muslim, Kitab 17 (Kitab Nikah), Bab 689, Hadis 2595.

${ }^{28}$ Shahih Bukhari, Kitab 47 (Kitab Nikah) Bab 2725, Hadis 4794
} 


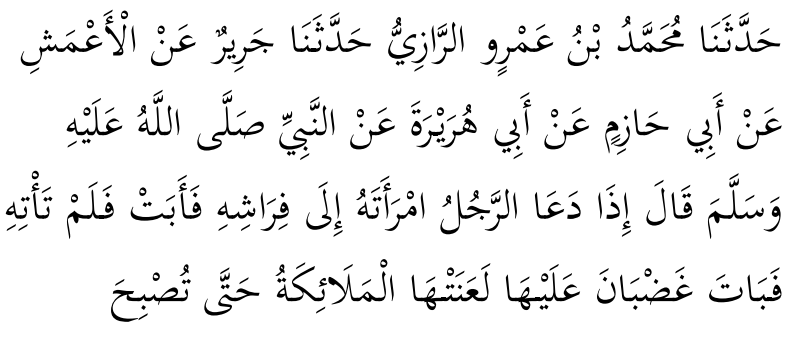

Telah menceritakan kepada kami (Muhammad bin 'Amr Ar Razi), telah menceritakan kepada kami (Jarir), dari (Al A'masy), dari (Abu Hazim), dari (Abu Hurairah) dari Nabi shallallahu 'alaihi wasallam, beliau bersabda: "Apabila seorang laki-laki memanggil isterinya ke ranjangnya (mengajak melakukan hubungan badan), kemudian sang istri menolak dan tidak datang kepadanya sehingga suaminya melewati malam (tidur) dalam keadaan marah, maka Malaikat akan melaknatnya hingga pagi." (HR. Abu Daud).

5. Darimi hadis 2131

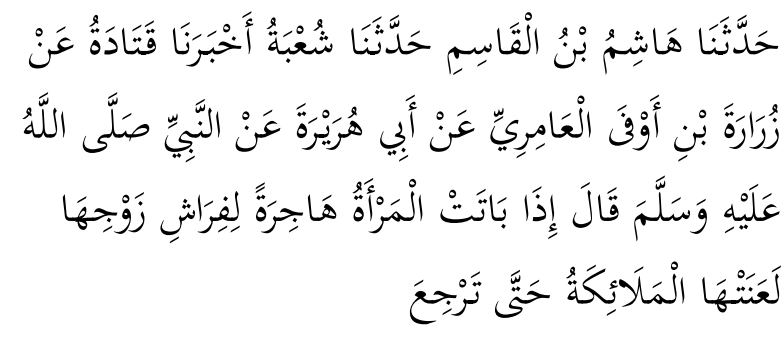

Telah menceritakan kepada kami (Hasyim bin Al Qasim) telah menceritakan kepada kami (Syu'bah) telah mengabarkan kepada kami (Qatadah) dari (Zurarah bin Aufa Al 'Amiri) dari (Abu Hurairah) dari Nabi shallallahu 'alaihi wasallam, beliau bersabda: "Apabila seorang isteri enggan bermalam dengan meninggalkan kasur suaminya, maka Malaikat melaknatnya hingga ia kembali." (HR. Darimi)

Secara tekstual, hadis pertama berkaitan dengan istri menolak ajakan suami untuk berhubungan seksual, sedangkan hadis yang lain berkaitan dengan istri tidur di tempat lain/kamar lain. Namun benang merah semua hadis tersebut berkaitan dengan kepatuhan istri terhadap suami dalam masalah seksualitas. Walaupun isi matannya berbeda di antara hadis-hadis tersebut namun yang menarik adalah intervensi malaikat berupa laknat malaikat terhadap istri ada pada semua matan hadis tersebut.

Hadis tentang intervensi malaikat dalam hubungan seksual suami-istri ini, para ulama dan ilmuan berbeda dalam memaknainya. Ada kelompok yang menerima hadis itu apa adanya secara tekstual, sedangkan kelompok yang lain mencoba untuk melihat dari konteksnya. Apabila hadis ini diartikan secara harfiah, maka menimbulkan ketakutan yang besar bagi istri untuk menolak keinginan suami. Padahal menurut Forum Kajian Kitab Kuning (FK3) yang menelaah Kitab U'qud al Lujjayn (mengaturrelasi suami-istri) dalam hadis di atas terdapat kata al-la'anah yang seringkali dipahami secara kurang tepat. Sebaiknya kata laknat dipahami dalam kontekssosial kemanusian, kasih sayang dan kedamaian dalam kehidupan. Jika diartikan secara kontekstual, hadis ini tidak hanya ditujukan kepada istri saja melainkanjuga kepada suami.

Muhyiddin Abdusshomad berpendapat bahwa hadis-hadis laknat bagi istri yang tidak melayani suami, itu harus diinterpretasikan sebagai motivasi terhadap istri agar selalu berusaha melakukan penyesuaian dengan suami, dan begitu juga sebaliknya. Istilah laknat itu sendiri tidak berarti haram. Buktinya para ulama fikih masih memberi batas apabila tidak ada udzur syar'i seperti sakit atau capek yang luar biasa. ${ }^{29}$

Adapun Mustafa Muhammad Imarah mengatakan, bahwa laknat malaikat itu muncul bila penolakan istri dilakukan "tanpa alasan". Sedangkan Wahbah az-Zuhaili berpendapat bahwa laknat itu terjadi apabila istri menolak senggama, padahal ia "sedang longgar dan tidak takut disakiti”. ${ }^{30}$

Perbedaan pandangan antara kelompok pertama dan kedua dalam memahami hadis di atas menurut Mas'udi disebabkan oleh perbe-

\footnotetext{
${ }^{29}$ Mahyudidn Abdusshomad, "Perkosaan Dalam Rumah Tangga” (Jakarta: Rahima, 2012).

${ }^{30}$ Wahbah Al-Zuhaili, Al-Fiqh al-Islam wa adillatuhu, VII (Damaskus: Dar al-Fikr, 1989),335.
} 
daan konstruk tentang seksualitas itu sendiri. ${ }^{31}$ Dari kalangan ahli fikih, seks bagi perempuan banyak diajarkan sebagai kewajiban. Hal ini terkait dengan pandangan konvensional masyarakat tradisional agraris bahwa seks adalah barang suci/sakral yang diciptakan Tuhan untuk menjamin keturunan (procreation). Sementara masyarakat kota beranggapan bahwa seks bagi perempuan selain untuk reproduksi juga untuk dinikmati (pleasure). Karena itu merupakan salah satu nikmat Tuhan.

Menurut Alimatul Qibtiyah, ${ }^{32}$ dalam melihat hadis tentang intervensi malaikat dalam hubungan seksual suami-istri ini ada beberapa hal yang perlu diperhatikan. Pertama, bagaimana bahasa yang digunakan dalam hadis tersebut (analisis bahasa). Kedua, bagaimana pendekatan fiqh yang digunakan (pendekatan hukum). Ketiga, bagaimana kondisi fisik dan psikologis yang baik dalam hubungan seksual bagi suami maupun istri. Keempat, apa sebenarnya makna dari laknat malaikat dalam hadis tersebut.

Keempat alternatif pemikiran terhadap hadis intervensi malaikat dijelaskan Alimatul Qibtiyah yang sebagai berikut:

\section{Analisis bahasa ${ }^{33}$}

Bahasa yang dipakai hadis ini perlu dicermati dengan seksama. Kata-kata ajakan suami dengan menggunakan iza da'a -da'ayad'u-da'watan (dakwah). Kata $d a$ 'a dalam Alquran ditemukan tidak kurang dari 198 kali dengan beberapa makna, diantaranya: memanggil, mengundang, minta tolong, meminta, memohon, menamakan, menyuruh datang, mendorong, menyebabkan, mendatangkan, mendoakan, menangisi dan meratapi. Dari makna yang berbeda tersebut sebenarnya semuanya tidak terlepas dari unsur aktifitas

\footnotetext{
${ }^{31}$ Masdar F. Mas'udi, Islam dan Hak-hak Reproduksi Perempuan: Dialog Fiqh Pemberdayaan (Bandung: Mizan, 2000).

${ }^{32}$ Alimatul Qibtiyah, "Intervensi Malaikat dalam Hubungan Seksual," dalam Perempuan Tertindas? Kajian Hadis-hadis "Misoginis," ed. Hamim Ilyas (Yogyakarta: eLSAQ Press, 2003), 209.

${ }^{33}$ Qibtiyah, "Intervensi Malaikat dalam Hubungan Seksual”,220-221.
}

memanggil. ${ }^{34}$ Aktifitas memanggil ini netral bisa untuk ajakan positif maupun negatif. Bila digeneralkan kata dakwah biasanya mengajak dengan cara yang baik, sopan, penuh bijaksana dan mengetahui benar kondisi yang diajak.

Penolakan istri atas ajakan suami dengan menggunakan kata fa'abat, dimana kalau dikaitkan dengan bahasa yang digunakan Allah dalam surat al-Baqarah ayat 34, ketika menggambarkan sikap iblis yang tidak mau sujud kepada Adam, maka Allah juga menggunakan kata $a b a$ yaitu berbunyi $a b a$ wastakbara, artinya "ia enggan dan takabur".

Jadi analisis bahasa ini dapat disimpulkan bahwa laknat malaikat akan benar-benar terjadi pada istri jika ketika sang suami sudah mengajaknya dengan penuh kesopanan, tidak memaksa dan dengan penuh pengertian dalam arti istri tidak sedang dalam keadaan uzur baik karena haid maupun alasan rasional lainnya.

2. Pendekatan Ushul al-Fiqh (Teori Hukum Islam)

Dalam memahami dan mengkaji teks, baik hadis maupun Alqurandapat menggunakan pendekatan Usul al-fiqh. Dalam Usul al-fiqh ada satu kaidah Qiroah Mubadalah, yaitu :

$$
\begin{aligned}
& \text { ما يَصْلُحُ لِأحد الجِنسين يُجْلبُ لِكِلَيهما وما يَضُرُّ }
\end{aligned}
$$

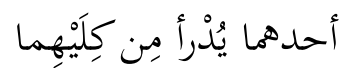

Apa yang maslahat bagi salah satu jenis kelamin terapkan bagi keduanya, dan apa yang mudarat bagi salah satu hindarkan dari keduanya.

Kaidah Ushul al-fighQiroah Mubadalahini dijelaskan oleh Faqihuddin Abdulqadir dalam kitab Manbaussaadah. ${ }^{35}$ Menurutnya, ketika memahami teks yang ada dalam hadis tentang laknat malaikat pada istri yang tidak mau melayani kemauan suami untuk berhubungan seksual adalah: jika istri dilaknat malaikat karena menolak berhubungan seksual dengan tidak sopan seperti iblis bahkan tanpa alasan syari (haid dan nifas), sedangkan suaminya mengajaknya dengan baik, dengan bahasa

\footnotetext{
${ }^{34}$ M. Ali Aziz, Ilmu Dakwah (Jakarta: Prenada Media Group, 2004), 6.

${ }^{35}$ Faqihuddin Abdul Kodir, Manbaussa'adah (Cirebon: Fahmina Institut, 2011), 48-49.
} 
dakwah, maka menurut teori hukum Islam Qiroah Mubadalah laknat malaikat juga akan berlaku pada suami yang menolak dengan tidak sopan ajakan istri tanpa alasan syari.

\section{Kondisi Fisiologis dan Psikologis ${ }^{36}$}

Seksualitas dalam Islam merupakan persoalan sensitif ketika dikaitkan dengan tatanan masyarakat muslim, maka Islam terlihat berpihak pada salah satu jenis kelamin, yaitu laki-laki. Al-Ghazali dalam Ihya 'Ulum ad-Din mengatakan bahwa pemuasan seksual akan disesuaikan dengan tingkat dan tekanannya. Laki-laki dapat menentukan jumlah istri lebih banyak karena laki-laki dikaruniai dorongan dan keinginan seksual yang kuat. Namun sebenarnya Ghazali selalu mengisyaratkan bahwa tidak terdapat perbedaan karakter dorongan seks laki-laki maupun perempuan. Dengan demikian secara tidak sengaja ia menyatakan suatu alasan yang ambivalen mengenai seksualitas perempuan dalam tatanan muslim.

Berbeda halnya dengan apa yang dikatakan oleh Syaikh Hasan al Bashri tentang seksualitas. Menurut dia, nafsu seksual perempuan itu lebih tinggi dibanding laki-laki. Menurut keterangannya, Allah menciptakan nafsu seksual itu sepuluh bagian. Sembilan milik perempuan dan satu milik laki-laki. Hal itu diutarakan ketika ditanya oleh Rabi'ah alAdawiyah.

Menurut Adhim hasrat berhubungan seksual laki-laki banyak berkaitan dengan fisiologisnya ${ }^{37} \mathrm{Hal}$ ini terjadi karena laki-laki akan menimbun sperma ketika ada gejolak, sehingga menuntut hasrat terpenuhi atau tersalurkan dengan segera. Sementara hasrat berhubungan seksual perempuan lebih banyak bersumber pada kebutuhan psikisnya untuk memperoleh kehangatan dan cumbu rayu dari orang yang dicintainya. Secara fisik tidak ada yang tertimbun sehingga tidak membutuhkan dengan segera untuk terpenuhi hasratnya. Semakin beragamnya pendapat tentang hasrat berhubungan seksual baik laki-laki maupun

\footnotetext{
${ }^{36}$ Qibtiyah, "Intervensi Malaikat dalam Hubungan Seksual",222.

${ }^{37}$ Muhammad Fauzil Adhim, Mencapai Pernikahan Barokah (Yogyakarta: Mitra Pustaka, 1999), 181.
}

perempuan menunjukan bahwa konstruk seksualitas sebenarnya tidak lepas dari tatanan sosial yang ada. Karena itu, perlu diteliti lagi, sebab bisa jadi setiap individu memang mempunyai dorongan seksual yang berbedabeda sehingga bukan ditentukan oleh jenis kelaminnya.

4. Makna Laknat Malaikat ${ }^{38}$

Mengenai arti laknat malaikat terhadap istri yang menolak atau menghindar ajakan suami perlu dilihat kembali. Menurut Alimatul Qibtiyah arti laknat perlu diinterpretasikan kembali, karena kata laknat itu seolah-oleh sesuatu yang sangat mengerikan dan menakutkan. Bahkan seolah-olah hubungan suami-istri adalah hubungan Allah dengan hamba-Nya, sehingga ketika suami marah atau kecewa maka malaikat pun juga akan ikut campur untuk menyelesaikan-nya. Padahal sebenarnya kalau kita lihat sampai ahir dari hadis tersebut hanya sebentar, karena katakata sampai istri kembali atau sampai datangnya waktu subuh. Kata laknat menurut Qibtiyah, dapat diartikan sebagai "suatu keadaan yang tidak menyenangkan". Ini akan dapat berubah menjadi hal yang biasa atau tidak jadi beban jika kedua belah pihak saling mengerti dan terbuka tentang masalah seksual.

Selain itu ada beberapa Hadis dan riwayat yang menunjukkan pandangan Nabi tentang perempuan. Menurut sebagian Hadis, Nabi Muhammad dan para imam yang salih semuanya telah menunjukkan secara terbuka kecintaan dan penghargaan mereka kepada istri dan kerabat perempuan mereka. Pada saat yang sama mereka sangat mencela setiap kecenderungan manusia yang mengarah pada kehidupan membujang atau kehidupan selibat.

Salah seorang sahabat Nabi, Usman ibn Mazh'un, mengabdikan dirinya semata-mata kepada pemujaan kepada Allah sedemikian rupa sehingga ia berpuasa setiap hari dan bangun di malam hari untuk shalat malam. Istrinya melaporkan hal itu kepada Rasulullah, lalu beliau memperlihatkan reaksi ketidaksenangan yang nyata, dan segera menuju ke tempat sahabatnya berada dan berkata:

\footnotetext{
${ }^{38}$ Adhim, Mencapai Pernikahan Barokah,223-226.
} 
Wahai Usman, ketahuilah bahwa Allah tidak mengutus aku untuk menganjurkan hidup kebiaraan. Shari'atku adalah untuk mendorong dan memudahkan pemenuhan kehidupan manusia yang alami.Aku sendiri mengerjakan shalat, berpuasa dan melakukan hubungan suami-istri.Karena itu, mengikuti aku dalam Islam berarti menyesuaikan din dengan sunnah-sunnah yang kugariskan, yang meliputi tuntutan bahwa laki-laki dan wanita harus kawin dan hidup sayang-menyayangi secara harmonis. ${ }^{39}$

Di masyarakat muslim pembicaraan tentang seksualitas biasanya dilakukan secara diamdiam dan tertutup karena topik ini dianggap sebagai sesuatu yang pribadi dalam relasi antar manusia. Hal ini diungkapkan seorang ulama yaitu Abu Syuqqah:

Pada masa Nabi di Madinah terjadi diskusi antara orang-orang Anshar dan Muhajirin tentang kapan seseorang wajib mandi jinabat. Lalu ada yang mengusulkan agar bertanya kepada Aisyah r.a.(istri Nabi). Di antara semua orang yang hadir tidak ada yang berani menanyakannya karena malu, sampai ada seorang yang memberanikan diri dan berkata: "Wahai Ummul Mukminin, saya ingin menanyakan sesuatu padamu, tetapi malu." Aisyah berkata: "Jangan malu bertanya kepadaku tentang sesuatu yang biasa kau tanyakan kepada ibu yang melahirkanmu, karena aku adalah ibumu." Lalu dia bertanya tentang hukum wajib mandi jinabat, dan Aisyah menjelaskan bahwa Rasulullah pernah bersabda: "Apabila lakilaki (swami) berada di antara empat anggota tubuh istrinya (antara kedua tangan dan kedua kakinya), dan zakar laki-laki masuk ke dalam vagina, maka wajiblah mandi. ${ }^{40}$

Rasa malu berkembang di kalangan Muslim, mungkin karena ada Hadis riwayat Bukhari dan Muslim yang berbunyi: Inna alhaya'a min al-iman, yang artinya bahwa malu adalah bagian dari iman. Maka, rasa "malu" semakin membuat persoalan sekitar seksua-

\footnotetext{
${ }^{39}$ Adhim, Mencapai Pernikahan Barokah, 10.

${ }^{40}$ Abdul Halim Abu Syuqqah, Kebebasan Wanita, 6 (Jakarta: Gema Insani Press, 1998),60.
}

litas menjadi tertutup. Meskipun banyak pemikir yang menganggap sudah saatnya masalah malu ditempatkan secara proporsional, karena tertutupnya segala sesuatu seputar seksualitas, justru membuat orang semakin penasaran dan menempuh cara yang salah untuk mengetahuinya. Dalam merespon hal ini, Abu Shuqqah secara terbuka menyatakan:

Seluruh anggota tubuh manusia itu suci dan mulia, baik alat untuk berpikir, alat-alat untuk makan dan minum, maupun alat-alat reproduksi.Demikian pula, seluruh perbuatan manusia adalah suci dan mulia jika dilakukan sesuai dengan syari'at Allah, baik berdagang, berperang, maupun melakukan hubungan biologis.Karena itu, wajarlah jika syari'at menyebut alat-alat reproduksi, aktivitas-aktivitas biologis, dorongan-dorongannya serta akibat dan hasilnya dalam situasi dan kondisi yang tepat, sebagaimana tidak terlarangnya menyebut tangan dan mulut, atau darah dan air mata. Karena itu, tak ada halangan pula untuk menyebut kemaluan danfarji, nuthfah dan mani. Tidak terlarang pula menyebut lapar dan puasa, atau menyebut memakan makanan dan meminum air. Demikian pula menyebut haid dan suci, atau menyebut bercumbu dengan istri atau menyentuh istri, asalkan dilakukan sesuai syara', dengan cara yang sopan, dan dengan tujuan untuk kemaslahatan kaum mukminin dan mukminat dalam urusan agama dan dunia mereka. $^{41}$

Sejalan dengan pandangan di atas, Murata, ${ }^{42}$ menyatakan bahwa banyak ayat Alquran dan Hadis Nabi-belum lagi sunnah atau perbuatan Nabi-yang menjadi dasar penilaian Islam yang secara umum positif mengenai hubungan seksual. Pada satu tingkat, Islam memandang hubungan seksual sebagai bagian yang alamiah dan normal dari ciptaan Tuhan. Dalam hubungan ini, pendekatan Islam mengikuti garis-garis pedoman yang terkenal, yang tidak membawa kepada rasa

\footnotetext{
${ }^{41}$ Abu Syuqqah, Kebebasan Wanita, 6, 66-67.

${ }^{42}$ Sachiko Murata, The Tao of Islam (Bandung: Mizan, 1996), 231.
} 
keterampasan dan frustrasi seksual, ataupun penindasan dan pelarangan dorongan seks. Islam bertujuan untuk mengatur seksualitas manusia dalam suatu cara yang paling alami, dan Islam tidak mengajarkan penindasan asketik terhadap nafsu seks ataupun nafsu alamiah yang lain.

Sama halnya dengan Mutahhari menyatakan bahwa nafsu seksual tidak saja sesuai dengan intelektualitas dan spiritualitas manusia, tetapi juga sebagai bagian dari watak dan temperamen para nabi. Karena menurut Hadis, cinta dan kasih sayang terhadap perempuan adalah karakteristik dari perilaku moral para nabi (min akhlaqi al-anbiya'i hubb annisai' $^{\prime}{ }^{43}$

\section{Seksualitas dalam Fikih Islam}

Fikih dalam makna generiknya adalah pengetahuan dan pemahaman tentang sesuatu. Sebagai disiplin ilmu, fikih dipahami sebagai suatu pengetahuan hukum Islam yang dirumuskan para ahli hukum Islam (mujtahid) melalui proses penalaran terhadap ayat-ayat Alqurandan teks hadis yang berhubungan dengan perbuatan manusia yang berakal dan dewasa. ${ }^{44}$ Sedangkan dalam terminologi $u s h u$ liyyun (para pakar usul fikih), fikih didefinisikan sebagai ilmu tentang hukum-hukum shara' yang bersifat praktis yang digali dari dalil-dalil yang terperinci. ${ }^{45}$

Hukum fikih dirumuskan biasanya sebagai jawaban dari berbagai persoalan atau kasus hukum yang berkembang di dalam masyarakat dan dalam kurun waktu tertentu. Oleh karena itu berbeda dengan teks Alquran dan hadis yang tidak bisa diubah, fikih malah bersifat dinamis dan fleksibel bisa berubah sesuai dengan perubahan kondisi, keadaaan, tempat dan waktu. Dalam suatu kaidah fikih disebutkan "perubahan fatwa hukum disesuaikan

\footnotetext{
${ }^{43}$ Murteza Mutahhari, Etika Seksual dalam Islam (Bandung: Pustaka, 1984), 8.

${ }^{44}$ Muhammad dkk., Fiqih Seksualitas, 27.

${ }^{45}$ Muhammad Abu Zahrah, Ushul al-Fiqh (Mesir: Dar al-Fikr, t.t.), 56.
}

dengan perubahan waktu, tempat, kondisi, niat dan tradisi". 46

Secara historis, terbentuknya wacana fikih bukan hanya sebagai upaya untuk mengimplementasikan pesan-pesan teks Alqurandan hadis dalam sebuah rumusan hukum yang bersifat praktis-realistis saja. Didalamnya terdapat unsur subjektifitas dan ideologi yang mencampurinya, disadari maupun tidak. Meskipun berawal dari sebuah panggilan keagamaan, tidak berarti fikih steril dari pengaruh (intervensi) nilai-nilai tertentu, baik idiologi, politik, ras, maupun budaya secara keseluruhan. Syafiq Hasyim mencontohkan Al-Mawardi ketika mengkonstruksikan fikih politiknya (figh al-siyasah) dalam bukunya $\mathrm{Al}$ Ahkam Al-Sulthaniyah, akan berbeda dengan rumusan fikih politiknya Ibn Taimiyyah yang menganut garis keras mazhab Hanbali, meskipun motivasi utama mereka sama yaitu mengaktualisasikan nilai-nilai siyasah Islamiyah dalam bentuk yang realistis dan empiris. ${ }^{47}$

Perbedaan dalam mengkonstruk wacana fikih didasarkan pada paradigma fikih yang berbeda. Paradigma adalah teori-teori, metode-metode, fakta-fakta, eksperimen-eksperimen yang telah disepakati bersama dan menjadi pegangan bagi aktivitas ilmiah para ilmuwan. ${ }^{48}$ Bidang fikih mengalami persaingan paradigma (paradigm war) yakni pertama dijumpai paradigma rasionalistik Hanafi yang kemudian ditolak oleh paradigma tekstualistik Maliki. Kemudian paradigma tekstualistik Maliki ditolak oleh sintesis teks dan rasio Syafi'i. Paradigma sintesis teks dan rasio Syafi'i ditolak oleh paradigma tekstualistik Ibn Hazm azh-Zahiri.

Dalam soal seksualitas perempuan, mazhab Hanafi yang memiliki paradigma rasionalistik

\footnotetext{
${ }^{46}$ Ibnu Qayyim al-Jawziyyah, I'lam Muwaqi'in 'an Rabb al-Alamin, 3 (t.k.: t.p., t.t.),3.

${ }^{47}$ Syafiq Hasyim, Hal-Hal Yang Tak Terpikirkan Tentang Isu-Isu Keperempuanan Dalam Islam (Bandung: Mizan, 2001).

${ }^{48}$ Lihat Thomas S Kuhn, The Structure of Scientific Revolution (Herndon: The University of Chicago Press, 1970), 11, 65.

${ }^{49}$ Sadari, "KDRT dalam Perspektif Fiqih," dalam Ragam Kajian Kekerasan Dalam Rumah Tangga, ed. Afwah Mumtazah (Cirebon: ISIF, 2012), 156.
} 
memiliki pandangan lebih maju. Menurut mereka, perempuan berhak menuntut hubungan intim kepada suaminya dan apabila istri menghendaki, suami wajib mengabulkannya. Mazhab Maliki juga menyetujui pendapat ini. Menurut mereka, suami wajib mengabulkan tuntutan seksualitas istrinya selama tidak ada halangan. Hubungan seksual harus dilakukan secara sehat. Ini berarti relasi seksual, dan kesediaan kedua pihak untuk saling menerima dan memberi hendaknya dilakukan secara tulus dan bukan paksaan. ${ }^{50}$

Relasi seksual suami-istri untuk saling menerima dan memberi ini diantaranya bisa terlihat dalam praktik pencegahan kehamilan dengan menggunakan metode senggama terputus (coitus interuptus/'azl). Untuk melakukan metode ini mazhab fiqih Maliki, mazhab Hambali dan mazhab Hanafi menjelaskan bahwa senggama terputus boleh dilakukan asal istri mengizinkannya. Hal ini dilakukan sebagai pemenuhan hak istri untuk merasakan kenikmatan seksual /orgasme yang biasanya tidak terjadi bila menggunakan metode tersebut sehingga suami wajib meminta izin dalam praktiknya. ${ }^{51}$ Bahkan dalam mazhab Maliki bila melakukan senggama terputus tanpa izin istri, maka suami wajib memberikan ganti rugi berupa uang. Jumlahnya lumayan besar yaitu membayar 10 dinar setiap kali senggama terputus dilakukan tanpa persetujuan istri. ${ }^{52}$ Bila diukur dengan rupiah, 1 dinar seharga Rp. 1,933,450 maka 10 dinar berarti Rp. 19,334,500. Hal ini menunjukkan betapa hak menikmati seksual bagi istri begitu diperhatikan.

\section{SIMPULAN}

Seksualitas dalam Islam dibentuk oleh nilai budaya dan agama. Nilai-nilai agama dalam Alquran, hadis dan fikih mewarnai pembentukan pandangan tentang apa yang boleh dilakukan atau tidak, berbagai keharusan, dan sikap yang dikembangkan sehubungan dengan

\footnotetext{
${ }^{50}$ Musdah Mulia, Muslimah Reformis (Bandung: Mizan, 2005), 249.

${ }^{51}$ B.F. Musallam, Seks dan Masyarakat dalam Islam (Bandung: Pustaka, 1985), 37.

${ }^{52}$ Musallam, Seks dan Masyarakat dalam Islam, 37.
}

peran jenis kelamin. Hal mendasar dalam konsep Alqurantentang seks/seksualitas ialah tidak membuat klaim yang merendahkan perempuan dan seks, bahkan menentang tradisi misoginis. Inti pandangan Alquran tentang seksualitas bahwa laki-laki dan perempuan memiliki karakteristik yang sama/serupa, termasuk karakteristik seksual misalnya terkait moralitas seksual atau kesucian. Sementara itu, inti dari hadis yang membahas seksualitas ialah hadis Rasul tentang kisah pernikahannya dengan Khadijah yang menunjukkan fenomena seksualitas perempuan yang aktif. Sumber hukum Islam ketiga yaitu fikih membahas seksualitas perempuan dengan pandangan lebih maju. Madhab Hanafi mengatakan bahwa, perempuan berhak menuntut hubungan intim kepada suaminya dan apabila istri menghendaki, suami wajib mengabulkannya. Mazhab Maliki juga menyetujui pendapat ini. Kedudukan perempuan dalam pernikahan merupakan hubungan setara, saling melengkapi dan saling membutuhkan sebagai patner.

Pandangan tentang seksualitas dalam Islam yang dijelaskan dalam ayat Alquran, hadis dan fikih begitu humanis dan sangat sejuk karena penuh empati kemanusiaan. Namun hal tersebut tidak banyak disosialisasikan di kalangan masyarakat Islam. Sebaliknya, pandangan yang banyak dijumpai atau pandangan dominan sangat bias nilai-nilai patriarki. Artinya hanya para suami yang mempunyai hak menikmati kepuasan seksual, sedangkan para istri hanya punya kewajiban memuaskan atau menuruti keinginan suami. Dari titik inilah salah satu pemicu timpangnya relasi suamiistri terjadi dan tidak menutup kemungkinan memunculkan tindakan kekerasan terhadap Istri.

\section{DAFTAR PUSTAKA}

Abdul Kodir, Faqihuddin. Manbaussa'adah. Cirebon: Fahmina Institut, 2011.

Abdusshomad, Mahyudidn. "Perkosaan Dalam Rumah Tangga." Jakarta: Rahima, 2012.

Abu Syuqqah, Abdul Halim. Kebebasan Wanita, 6. Jakarta: Gema Insani Press, 1998. 
Abu Zahrah, Muhammad. Ushul Al-Fiqh. Mesir: Dar al-Fikr, n.d.

Adhim, Muhammad fauzil. Mencapai Pernikahan Barokah. Yogyakarta: Mitra Pustaka, 1999.

Al-Thabari, Abu Ja'far Muhammad bin Jarir. Jami' Al-Bayan Fi Tafsir Al-Qur'an, III. t.p., n.d.

Al-Zuhaili, Wahbah. Al-Fiqh Al-Islam Wa Adillatuhu, VII. Damaskus: Dar al-Fikr, 1989.

Aziz, M. Ali. Ilmu Dakwah. Jakarta: Prenada Media Group, 2004.

Barkat, Halim. Dunia Arab. Translated by Irfan M Zakki. Bandung: Nusa Media, 2012.

Barlas, Asma. Cara Qur'an Membebaskan Perempuan. Jakarta: Serambi, 2003.

Dermawan, Andi. "Marital Rape Dalam Perspektif Hukum Al-Qur'an." In Tela'ah Ulang Wacana Seksualitas, edited by Mochammad Sodik, I. Yogyakarta: PSW IAIN Sunan Kalijaga, Depag RI dan McGill-IISEP-CIDA, 2004.

Dwiyanto, Agus, and Muhadjir, eds. Seksualitas, Kesehatan Reproduksi Dan Ketimpangan Jender. Jakarta: Pustaka Sinar Harapan, 1996.

Engineer, Ashgar Ali. Hak-Hak Perempuan Dalam Islam. Translated by Farid Wajidi dan Cici Farkha Assegaf. Yogyakarta: Yayasan Bentang Budaya, 1994.

Hamka. Tafsir Al-Azhar, II. Jakarta: Pustaka Panjimas, 1983.

Hasyim, Syafiq. Bebas Dari Patriarkhisme Islam. Jakarta: Kata Kita, 2010.

—. Hal-Hal Yang Tak Terpikirkan Tentang Isu-Isu Keperempuanan Dalam Islam. Bandung: Mizan, 2001.

Ibnu Qayyim al-Jawziyyah. I'lam Muwaqi'in 'an Rabb Al-Alamin, 3. t.k.: t.p., n.d.

Jackson, Stevi, and Sue Scott. Feminism And Sexuality: A Reader. New York: Colombia University Press, 1993.
Kuhn, Thomas S. The Structure of Scientific Revolution. Herndon: The University of Chicago Press, 1970.

Lebacqz, Karena. Sexuality: A Reader. Edited by Karena Lebacqz. Claveland, Ohio: The Pilgrim Press, 1999.

Mas'udi, Masdar F. Islam Dan Hak-Hak Reproduksi Perempuan: Dialog Fiqh Pemberdayaan. Bandung: Mizan, 1997.

Mernissi, Fatima. Beyond The Veil: Seks Dan Kekuasaan Dinamika Pria Wanita Dalam Masyarakat Muslim Modern. Surabaya: AlFikr, 1997.

Muhammad, Husein. "Íslam, Seksualitas Dan Budaya." Swara Rahima 20, no. XII (2012).

Muhammad, Husein, and Dkk. Fiqih Seksualitas. Jakarta: PKBI, 2011.

Mulia, Musdah. Muslimah Reformis. Bandung: Mizan, 2005.

Murata, Sachiko. The Tao of Islam. Bandung: Mizan, 1996.

Musallam, B.F. Seks Dan Masyarakat Dalam Islam. Bandung: Pustaka, 1985.

Mutahhari, Murteza. Etika Seksual Dalam Islam. Bandung: Pustaka, 1984.

Qibtiyah, Alimatul. "Intervensi Malaikat Dalam Hubungan Seksual.” In Perempuan Tertindas? Kajian Hadis-Hadis "Misoginis," edited by Hamim Ilyas. Yogyakarta: eLSAQ Press, 2003.

Sadari. "KDRT Dalam Perspektif Fiqih." In Ragam Kajian Kekerasan Dalam Rumah Tangga, edited by Afwah Mumtazah. Cirebon: ISIF, 2012.

Truongh, Thanh-Dam. Seks, Uang Dan Kekuasaan: Pariwisata Dan Pelacuran Di Asia Tenggara. Jakarta: LP3ES, 1992.

Wahid, Marzuki. "Mendaulatkan Seksualitas Perempuan." Swara Rahima 5, no. II (2009). 